\title{
The Relationship between the Concept of Wasatiyyah and the Values of Budi-Islam in Reinforcing Ethnic Relations in Malaysia
}

\author{
Wan Norhasniah Wan Husin
}

\begin{abstract}
The concept of Wasatiyyah or moderation was proposed by current Prime Minister, Najib Abdul Razak, with the aims of fostering harmony among the diverse ethnics in the country. Even though some negative perceptions were voiced by a few parties, but the actual intentions could result in a decline of racial strains, as being moderate has been the practice of the Malay community and its leaders for ages. In fact, this approach has contributed to the success of the Malay community in securing independence from the British in an amicable manner, without having to resort to spilling a lot of blood. Based on previous research, it was observed that the concept of Wasatiyyah had a great influence on the Malays, as it had a strong link with the values of budi-Islam that have been embedded in the Malay community. The budi-Islam values are the main elements that shape the Malays' conduct, and it is the results of interaction with social norms, for it has bred certain social values that include compromise, modesty, respect and cooperation as transpired when Malays interact among themselves or with other communities. The main goal for the Malays is to maintain peace in the society. Hence, when Najib announced the enhancement of the concept of Wasatiyyah in bracing racial ties in Malaysia; the study finds that it is not exactly a new concept, but more towards a reinforcement of a Malay leader's traditional administration approach when interacting with the community. Based on textual analysis, the study determines that the concept of Wasatiyyah concept or moderation is part of the social values borne out of the Malays' values of budi-Islam.
\end{abstract}

Index Terms-Ethnic relations, malay community, the concept of Wasatiyyah, the values of budi-Islam.

\section{INTRODUCTION}

Compromise between the citizens of any country is vital especially for a multi-racial nation that is founded upon a diverse ethnic background. In order to ensure that unity and harmony are maintained within a society, there are nations that resort to implementing assimilation methods like the United States of America [1], France [2] and Indonesia [3], where the minority communities are expected to discard their traditional identity and embrace the fundamental principles of the country's natives. Even though the method administered succeeded in upholding the traditions of the natives, but the government's strict handling on the issue often discriminates the minorities, which have led to racial strains among the masses. However, ethnic relations in Malaysia tread upon a totally different path.

Manuscript received May 21, 2013; revised July 22, 2013

Wan Norhasniah Wan Husin is with the National Defence University of Malaysia, Sungai Besi Camp, 57000 Kuala Lumpur, Malaysia (e-mail: hasni_wan02@yahoo.com,hasniah@upnm.edu.my).
It also Malaysia is a new nation that was built upon three major ethnics, that are the Malays as the indigenous ethnic that form the majority, the Chinese, the main minority group, and the Indians. The Chinese and Indians were originally immigrants that came to Malaya with the aims of seeking greener pastures. With the society's diverse background, the efforts to foster unity in order to attain independence was quite difficult as each community held on to different cultural traditions and civilizations. Hence, to maintain peace, the Malay leaders took the initiative to observe the spirit of moderation by being tolerant and cooperative in enacting government policies to foster harmony between the ethnics. Being moderate, tolerant, and cooperative are the foundations of the values of budi-Islam that have been inculcated in the Malays since time immemorial [4].

Currently, the spirits of moderation and tolerance have been put into prominent through the concept of Wasatiyyah by Najib Abdul Razak. The concept is seen as the best means to unite the people of Malaysia that are made up of dissimilar ethnic backgrounds, as it preserves the spirit of conciliation as the government strive to reinforce the nation's administration system, economic stability, religious issues and racial relations [5].

Based on previous research, this study discovers that the concept is nothing new as the moderate administration style had been implemented by preceding Malay leaders, which could be traced to the days of the Malacca Sultanate kingdom. The characteristics and ideas continue to be relevant to the present as the values of budi-Islam have been infused in the heart and soul of the Malays [4].

From the analysis carried out, it was found that studies that relate to the concept of Wasatiyyah with the values of budi-Islam have not been carried out by any researcher. Even though Zainal Kling did indicate a link between Wasatiyyah and budi, but no direct association was made with regard to the ethnic relations in Malaysia [6]. Most research concentrated on separate discussions between the concept of Wasatiyyah and the values of budi-Islam. There was also an explanation on the concept of Wasatiyyah from the perspective of Islam by Ismail Ibrahim [7] and Jamil Khir [8]. Meanwhile, the concept was generally defined by Najib Abdul Razak [9], [10]. Among researchers that have joined the debate in deliberating the roles of budi in the lives of the Malays are Zainal Kling, who offered his views in 'Adat' [11] and 'Sistem Nilai Tradisi Melayu' [12]. Besides, Wan Abdul Kadir [13] described 'budi' as social values that include compromise, tolerance, respect, modesty and mercy. Wan Norhasniah Wan Husin [4], in the book titled 'Peradaban dan Perkauman di Malaysia: Hubungan Etnik 
Melayu-Cina' focused more on how the values of budiIslam play an important role in shaping the identity and characters of the Malay community, especially when they interact with others.

Hence, the main objective of the study is to prove that the concept of Wasatiyyah is closely related to the values and principle elements of budi-Islam. The values are considered second nature to the Malays, which have a great influence on the community's actions and ideas since the golden days to the present day. Therefore, it is not exactly a new concept among the Malays since leading a life of moderation and knowing how to compromise have perpetually been a part of their life [13], [11], [14]. To fulfill the objectives of the study, the text analysis method was applied to verify the relationship between the concept of Wasatiyyah and the values of budi-Islam. Based on the study, it was established the concept is directly related to the budi-Islam values. In fact, it is the fundamental elements that play a huge role in influencing the Malays' characteristics and mindset.

\section{THE RELATIONSHIP BETWEEN THE CONCEPT OF WASATIYYAH AND THE VALUES OF BUDI-ISLAM}

\section{A. The Concept of Wasatiyyah}

The term Wasat carries the meaning of 'average', and is also referred to as 'fair, 'the best, 'the respected and 'the chosen'. From the aspect of definition, there are some Islamic scholars that translate it as 'fair judgment', or could also be considered as 'reasonable', 'equal', and 'central point'. In the Malay realm, the notions of Wasatiyyah that originate from Islam were regarded as the 'average' and 'moderation' [6].

The stance of observing average and moderation are the Malay community's way of life when interacting, whether among themselves or with other non-Malay communities. The concept was further cultivated in the soul of the Malays when Islam arrived in the Malay realm around the $7^{\text {th }}$ A.D. As a result, the Malays resorted to enhancing the concepts in performing their daily activities, such as when interacting with others in order to heed to the teachings of Islam [5].

\section{B. The Values of Budi-Islam}

The values of budi refer to a set of internal values that shape one's mentality and personality. It then percolates in the relations formed with family and society, and the sense of responsibility in guiding one's manners and actions. The emergence of this internal value is different between societies as it all depends on each community's expectations It embedded in the mind of the community which started from individual and later became the binding principle elements in shaping the Malay community's character. The close association between budi and the Malay cultural values is coined in the word budaya. Budi is spiritual sometime referred to as the 'soul' (roh); while daya is reflected in physical actions. It is a combination of the words budi and daya known as budaya or culture that shows a manifestation of the action of Malay soul or the traditions of the Malay. The upmost aim of budi is to uphold peace and harmony in their relationship with others [12]. This is reflected in the Malay perbilangan, 'If it is good to you then it is good to me, unanimously agreed, harmoniously discussed, consensually cooperated' (Baik pada awak maka baiklah pada saya, Seiya sekata, Berunding beriya, Bulat kata kerana muafakat) [11]. It is permanent in nature, but has dynamically undergone various transformations to suit the ever-changing environment. If there were external elements that suit the core aims of budi, they will be assimilated, however budi character will remain intact. The only changes are the actions that were expressed differently [4], [13].

The values of Budi-Islam are the elements that form the fundamental principles of the Malays' identity, be it at the individual level, or at the community level. The emergence was natural, as it was already infused within the souls of the Malays. Budi is the foundation in the Malays' spirits that influence their actions when interacting with other people in order to achieve unity and harmony in the society [12], [14]

The founding of the Malays' identity is closely related to the role of budi values that form the personality and disposition of the Malays, which is the result of the combination of the mind and emotion. Through the mind, the Malays reflect and execute decisions that conform to the requirements of the virtue, moral values and ethics in order to consider the needs of self and others, like the saying, 'think of others and listen to what others have to say'. When Malay starts to think about others, which is the root of moderation or Wasatiyyah that rejects all forms of extremism. The fostering of the Malays' sensitive personality is due to their cultured, traditional and courteous nature. Meanwhile, emotion plays a role in forming an intellectual ability that is refined and ethical which give birth to an inner sensitivity that is insightful towards its surroundings. The sensitivity is articulated through speeches of tolerance and expression which symbolize the Malays' civilized and artistic state of mind.

The fine tradition is aptly expressed in their tolerance and conscience that exhibit the Malays' highly refined and artistic wisdom. It is the result of intelligence, emotion and sentiment that requires decency from a person [12]. In building an identity and personality while interacting within the community or with other ethnics, budi is articulated through three fundamental principles. The first one is 'courtesy', one's wisdom when communicating; 'disposition', that reflects a polished personality; and graciousness that illustrates refined manner [11]. Hence, 'budi demonstrates an entity of refined behaviour, language expression, and interaction skills through the application of wisdom expressed through modest actions and considerate nature.

Other than the customary system, the values of budiIslam are reinforced through nature, as the Malay Peninsula is a sacred land surrounded by the seas and islands. The geographical surrounding had contributed to the strengthening of budi through the influence of the philosophies of water and spirit of the paddy. By nature, water has the elements of grace and modesty, while paddy exhibits the rudiments of humility, where the 'more it possesses, the humbler it becomes'. Hence, these values are the fundamentals that form budi that in turn influences the Malays' heart and soul. For example, a revered Malay individual is one that is modest, as the wiser one is, the more graceful and humble he turns out to be. The Malay 
Peninsula's climate and location is geographically ideal, as it is protected from any natural disasters. Hence, the idyllic surroundings had indirectly influenced the Malays' nature into being modest in every aspect of their life [4].

The influence of budi-Islam, the customary system and geographical location have no doubt contributed to the gentle nature of the Malays that is highly refined in being modest, tolerant, respectful and accommodating, elements that are second nature to the Malay community in every aspect of their life.

\section{THE RELATIONSHIP BETWEEN THE CONCEPT OF WASATIYYAH WITH THE VALUES OF BUDI-ISLAM}

The aspirations of leading a modest life, or Wasatiyyah among the Malays, are enacted in the concept of budi. It is viewed as a broad value in life as all aspects of the Malays' life, such as their traditions, culture, politics, economy; social relations and religion are based on the values of budi [6]. The understanding of the value is expressed through their actions of tolerance, modesty, respectful and accommodative whenever they communicate among themselves, or with other ethnic communities [4].

Based upon the principles, the Malays would definitely evaluate every request, whether from their own community or others, from the aspect of the budi elements. However, the evaluation and action practiced by the Malays could lead to conflicts, or even amok, if they are overly provoked. This is best exemplified by the history of Singapore's inclusion and expulsion from Malaysia [6].

\section{The AtTESTAtion RELATIONSHIP BETWEEN THE CONCEPT OF WASATOYYAH WITH THE VALUES OF BUDI-ISLAM OF THE INFLUENCING ETHNIC RELATIONS IN MALAYSIA}

\section{A. The Pre and Post-Independence Era}

The Malays' highly esteemed manner in expressing modesty and tolerance was exhibited during the Melaka Malay Sultanate kingdom when the Sultan pleaded for protection from the Ming Emperor from the threat of the Javanese kingdom. The liaison between the two kingdoms was fortified when the Malacca Sultan adhered to the Emperor's request by sending an envoy bearing tributes for the Emperor. In fact, the Sultan was prepared to lead the envoy in order to protect his people and political territory. By being accommodating, moderate and cooperative, the kingdom was granted dividends when it was recognized by the Chinese Emperor, elevating it to an equivalent status as other Southeast Asia kingdoms. Even though the Javanese kingdom protested vehemently, but when the Ming dynasty placed their armada with strength of 37,000 soldiers in Melaka, the Javanese backed off. Apart from that, the relation also paid off handsomely as a result of peace and stability the port of Malacca was flourishing not only to this region but in the West as well [15].

In the history of social relations between the Malays and non-Malay communities, severe conflicts and clashes rarely take place. The Malays' tolerant, cooperative and respectful manners have led them to being labeled as a community that is open-minded and approachable. Hence, they have no problems to form alliances with traders from Arab, Persia, China, India and other regions, which led to the recognition of the Melaka port as an international trading centre in this part of the world. The continued increase of traders' arrival was not only attributable to the good governance and treatment from administrators and locals, but also due to the Malays' approach in implementation of Islam which slightly differed from the Arab's way. They were deemed to be more open, accommodating and moderate in implementing Islamic teachings compared to the Arabs, who were more stringent and pessimistic in executing their obligations, including the ways they treat non-Muslims [16]. This accommodating attribute is also acknowledged by the Chinese immigrants. The accepting nature had also allowed the opportunity for migrant communities to open their own settlements in the Malay Peninsula, such as the Chinese settlements in town areas and Indian settlements in estates [17].

In the post-independence period, which was obtained with the cooperation among the Malays, Chinese and Indians, the objective of fostering harmony between the masses was achieved with the Malay leaders' insistence upon implementing the spirit of moderation and cooperation. In the early days of independence, the method applied by the government to achieve unity was through integration and not assimilation, where no minority ethnic was forced to discard their traditions and accept the majority Malays' culture. The integration method was enforced to bolster harmony and prevent discrimination as expressed by Abdul Razak who preferred integration against malice [11]. The Malays' modest nature could be glimpsed from the aspects of religion and culture. From the religious aspect, even though it is enacted in the Federal Constitution that Islam is the official religion of Malaysia, but the government allows the non-Muslims the freedom to practice their faith without any restrictions [18]. The moderate stance is also applied by Najib Abdul Razak administration, as it is the utmost aim of every faith to perform good deeds, hence the belief that all religions would aspire to seek for the means to unite all races in Malaysia [19].

In terms of culture, the recognition of the Malay's culture as the foundations of Malaysian National Culture was not easily accepted by other ethnics, as they initially viewed the act as an attempt by the Malays to dominate their culture through the assimilation process [20]. However, after the May 131969 racial riots, Abdul Razak, the second Prime Minister of Malaysia took the initiative to outline three principles of the National Culture that reveres the status of the natives and minority communities in Malaysia. Among the principles enacted is that the National Culture must be founded upon the traditions of the natives of the land. Another important aspect is the recognition of Islam as the main element that forms the basics of the national culture. The third principle states that there are possibilities that aspects from other cultures that suit the people of the nation could be accepted as elements of the national culture [21].

By inculcating the Malays' spirit of moderation and accommodating, the Malaysian Chinese are granted the freedom to observe their traditions, such as by celebrating the Chinese New Year festival and Wesak Day, and 
performing the dragon dance. The Hindus also face no obstacle in executing their religious obligations. One of the Hindu's major distinctions is to have enacted the biggest Hindu statue in Southeast Asia, which is situated in Gombak near Batu Caves area. Although the Islamic values play the leading role in developing the integrity of the Malays and the Malayness that resulted in the formation of PAS, the party that struggles for the full implementation of Islamic teaching, the tolerant and moderate attitudes prevailed and the rights of non Muslim to freely practice their religion are observed. For example, the Kelantanese PAS government has granted the permission to build the second biggest Buddhist statue in the world in the district of Tumpat [5], [22].

\section{CONCLUSION}

From the above premises, it could be concluded that the spirit of moderation or the concept of Wasatiyah has been deeply embedded or ingrained in the mind of the Malays. The thinking of considering the feeling of others while making a decision is the root in moderate thinking's and actions. The concept has been found to have been practiced since the birth of Malay Kingdom in peninsula and continues till the present day administration.

\section{ACKNOWLEDGEMENTS}

We wish to offer our gratitude for the opportunity extended by Yayasan Pembangunan Ekonomi Islam Malaysia (YaPEIM) to present the paper at this conference.

\section{REFERENCES}

[1] J. Hector, Letters from American Farmer and Sketches of $18^{\text {th }}$ Century America, New York: Penguin, 1981.

[2] A. G. Hargreaves, Immigrant, Race and Ethnicity in Contemporary France, New York: Routledge, 1995.

[3] T. T. W. Tan, Your Chinese Roots: The Overseas Chinese Story. Singapore: Times Books International, 1986.

[4] W. N. Wan Husin, Peradaban dan Perkauman di Malaysia, Kuala Lumpur: Universiti Malaya, 2012.

[5] B. H. Wasatiyyah, "Satukan Masyarakat Pelbagai Kaum di Malaysia," Nik Salida Shuhaila, 9 Jun 2012.

[6] Z. Kling, Konsep Wasatiyyah: Perspektif Sosial Sains, Konvensyen Wasatiyyah, Kuala Lumpur, 2012.

[7] I. Ibrahim, Konsep Wasatiyyah dari perspektif Islam, Konvensyen Wasatiyyah, Kuala Lumpur. 2012.

[8] J. Khir, Konsep Wasatiyyah Pendokong Gagasan Satu Malaysia, Jabatan Kemajuan Islam Malaysia, Kuala Lumpur, 2010.

[9] N. A. Razak, Bernama Konsep Wasatiyyah Satu Pendekatan Untuk Keamanan Sejagat, Mar. 13, 2012.

[10] N. A. Razak, The Malaysian Insider, Malaysian Moderation Concept well-received, November 6, 2012.
[11] Z. Kling, "Melayu Baru: Pencerahan Adat dan Adab, dalam," in Proc. Simposium Melayu Baru, Kuala Lumpur: ITC Book Publisher, 1993.

[12] Z. Kling, "Manusia Melayu, Alam dan Tamadunnya," Antara Patriotisme dan Globalisasi, Hari Sastera Anjuran bersama Kerajaan Negeri Melaka dan GAPENA, 1995.

[13] W. A. Kadir, Budi Sebagai Asas Budaya Melayu, Petaling Jaya: Masfami Enterprise, 1993.

[14] W. N. W. Husin. "Budi-Islam: It's role in the construction of malay identity in Malaysia," International Journal of Humanities and Social Science, vol. 1, no. 12, 2011.

[15] G. W. Wang, "The first three rulers of Malacca," JMBRAS, 1968, vol. 40, no.1.

[16] L. Filipe, "Masyarakat Melayu Menjelang Penaklukan Portugis: Satu Interpretasi Tentatif Berdasarkan Dokumen Portugis yang Masih Ada hingga Kini, dalam," Tamadun Melayu, Kuala Lumpur: Dewan Bahasa dan Pustaka, 1993.

[17] T. C. Beng, Baba and Nyonya: A Study of Chinese Peranakan in Malacca, New York: Cornell University, 1975.

[18] Kedudukan Islam Dalam Perlembagaan Malaysia. (Akses pada 2 Jun 2007). [Online]. Available: http://www.islam.gov.my.

[19] Bernama, Konsep Wasatiyyah mampu pupuk perpaduan kaum Najib, 17 Mar. 2012.

[20] K. J. Ratnam, Communalism and the Political Process in Malaysia, Kuala Lumpur: University Malaya, 1965.

[21] A. L. A. Bakar, "Sejarah dan Pemikiran Konsep Kebudayaan di Malaysia," Pertemuan Dunia Melayu 82, Perhimpunan Kebangsaan dan Serantau Sempena 25 Tahun Malaysia Merdeka dan Kongres Kebudayaan Melayu Pertama, Dewan Bahasa dan Pustaka, 1982.

[22] Utusan Malaysia, 30 July 2001.

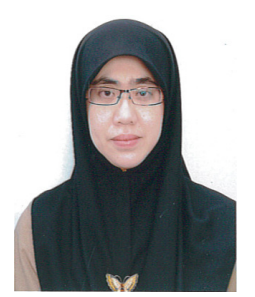

Wan Norhasniah Wan Husin was born in Besut Terengganu, Malaysia on 22 February 1972. She obtained her bachelor degree in Islamic studies from international Islamic University in 1996, and her master degree in Islamic politics in University of Malaya, Malaysia in 2002. Then she continued her study at $\mathrm{PhD}$ level in ethnic politics at University of Malaya and graduated in 2010. Currently she is an associate professor at national defence University of Malaysia. Her major research areas are ethnic politics, Islamic criminal laws, and civilization and culture. She has authored a number of papers published in international as well as local journals. Among the papers published in 2011 are 'Budi-Islam: It's Role in The Construction of Malay Identity in Malaysia, Nation-Building and 1Malaysia Concept: Ethnic Relations Challenges in The Educational Fields and An Analysis of Ethnic Relations between the Malay and Chinese Communities in Malaysia from Civilizational Perspectives: Language and Education Experiences. All the above papers were published by International Journal of Humanities and Social Sciences. So far she has authored two books, which are 'Peradaban dan Perkauman di Malaysia; Hubungan etnik Melayu-Cina' (Civilization and Communalism in Malaysian: Ethnic Relations of The Malays and Chinese), and 'Hukuman Bunuh ke atas Pengedar Dadah berdasarkan Siyasah Syari'yyah' (Death Penalty to Drug Traffickers According to Siyasah Syariyyah). Both were published by University of Malaya publication.

Dr Wan Norhasniah Wan Husin also involves in professional activities. She is a member of Scientific and Technical Committee \& Editorial Review Board on Human and Social Science (International). She also a National Committee member for course of Islamic and Asian Civilization, and she has been the member of Social Science Association of Malaysian since 2009. 